\title{
The Social Phenomenon of Women Empowerment in Nigeria: A Theoretical Approach
}

\author{
Eucharia N. Nwagbara ${ }^{1}$, Grace R. Etuk ${ }^{1}$, Michael Baghebo ${ }^{2}$ \\ ${ }^{1}$ Department of Sociology, University of Calabar, Calabar, Nigeria \\ ${ }^{2}$ Department of Economics, Niger Delta University, Wilberforce Island, Nigeria \\ Email: eucharia_n@yahoo.com
}

Received July $8^{\text {th }}$, 2012; revised August $14^{\text {th }}, 2012$; accepted August 22 ${ }^{\text {nd }}, 2012$

\begin{abstract}
Women have continued to make immense contributions to development in Nigeria. These landmark achievements have not been without challenges, hence the predominance of women issues at local, national and international seminars, workshops and symposia. Issues such as women's status, roles, and needs have been of utmost concern. Efforts to address these issues led to the adoption of various strategies towards making women relevant in every sphere of life in the society. One strategy that had gained currency over the years among scholars and practitioners of women and gender studies has been that of women "empowerment". The continued persistence of women's problems in the areas of gender equality, gender roles, improved social status, etc., raises a number of questions about the empowerment strategies of governmental and non-governmental agencies. Are the strategies based on faulty theoretical assumptions? Is their application in the Nigerian situation faulty? What is the problem of their application in the Nigerian context? This paper attempts to examine these questions against the background of the tenets of women empowerment strategies.
\end{abstract}

Keywords: Empowerment; Women Participation; Gender Issues; Women’s Status; Policy

\section{Introduction}

Gender and women's studies have come a long way in Nigeria since the first United Nations world conference on women held in Mexico City in 1975 (Ogbuagu, 2004; Gabriel, 2000; Nwagbara et al., 2007; Salihu, 2001; Para-Mallam, 2006; Ogunleye \& Mukhtar, 2009; Afolabi, 2008; Adeleke, 2012). One common thread that runs through these studies is the affirmation of the enormous contributions made by women to development in the face of socio-cultural, economic and health constraints.

Women in Nigeria have continued to make immense contribution to national development in their various areas of endeavors in addition to domestic responsibilities which are undervalued. In the area of agriculture, rural women in Nigeria, like their other African counterparts have played key roles in food production, processing and distribution. As scholars have observed, rural women in Nigeria like their counterparts in other African countries have been seen to excel in agricultural production (Famoriyo, 1988; Adekanye, 1988; Ogbuagu, 2004). The enormity of their contribution in this sector of the economy has made Boserup (1980) to proclaim Africa as the region of female farming. Yet they face the problem of access to credit facilities, ownership of land, and overwhelming domestic chores, discrimination and marginalization, among others.

In the modern employment sector, women have shown evidence of efficiency and effectiveness through hard work, honesty, transparency and accountability in their service to the country even though they are marginalized and discriminated against. Thus women like Dora Akunyili and Ngozi-OkonjoIweala, to mention but a few, have recently become household names in Nigeria due to their outstanding contribution to national development in their respective positions. These are few privileged ones out of the many women that lack opportunities due to patriarchal traditional practices that relegate them to subordinate status in the society. Yet women constitute about half of the population in Nigeria according to the 2006 population census (Rotimi \& Agande, 2007). This unfortunate situation raises some pertinent questions as follows: why is the status of women generally low in spite of global efforts towards its upgrading? What is happening to women empowerment in Nigeria? These and more will guide our discussion in the remaining part of the paper. The paper presents a multi-varied and prismatic view of the problems of women which still remain to be solved in the world in general, and particularly in the Nigeria.

\section{Methodology}

This is a theoretical paper in which the authors tried to stimulate general intellectual curiosity on the persistent problem of women empowerment in Nigeria, hoping that new and innovative strategies for attaining gender equality will emerge at the end. The paper is fundamentally based on library research enriched with internet resources and government publications.

\section{Conceptualizing Empowerment}

The concept of "empowerment” has been diversely used by scholars and practitioners in the field of gender and development studies. According to Crawley (1998), the concept of empowerment itself is used to "justify development propositions which are rooted in diverse ideological political positions" and thus is fraught with mixed reactions among people. This observation is evident in the contrasting views of Griffen (1989) and Rowlands (1992) on empowerment. In reacting to Griffen's 
(1989) description of the term as adding to women's power, Rowlands (1992) observes that such definition raises confusion as the concept of power itself is much disputed.

When we put together the various views on the empowerment debate, it becomes obvious that the concept goes beyond the issue of participation. As Crawley (1998) aptly observes, "it is more than simply widening access to decision-making”. Defining the concept, Gajanayake (1993) notes that empowerment implies "enabling people to understand the reality of their situation, reflect on the factors shaping that situation and, most critically, take steps to effect changes to improve it". This view was re-echoed by Ake (1994) who sees the term as a process that enables the ordinary people to effectively participate in governance. In the view of Garba (1997), women empowerment involves enhancing their capacity to influence and participate in making decisions which directly or indirectly affect their lives. Garba further distinguished between static and dynamic dimensions of empowerment which was summarized by Gabriel (2000) thus:

"The static concept defines empowerment of women as their capacities to participate in making decisions which directly or indirectly affect their lives and influence decision. In this regard, women are said to have effective voice. On the other hand the dynamic concept regards empowerment as a process of developing the capacity of individuals... to not only participate effectively in making decisions that directly or indirectly affect them but also in implementing such decisions."

Essentially, empowerment must include the processes that lead the individual or group to perceive itself as able to occupy a decision making position. In other words, "an empowerment focus involves the radical alteration of the structures which reproduce women's subordinate position as a gender" (Crawley, 1998).

\section{Women Empowerment in Nigeria: The Journey so Far}

Globally, United Nations organs such as the United Nations Development Programme (UNDP) and United Nations Population Fund (UNFPA) have continued to play key role in women empowerment. According to the UNFPA, the empowerment of women is a sure way to attaining gender equality

(http://www.unfpa.org/gender/empowerment.htm). As part of its activities toward the attainment of the Millennium Development Goals and sustainable development, the UNDP vigorously initiates programmes and activities aimed at fast-tracking gender equality and women's empowerment in many societies (http://www.undp.org/content/undp/en/home/ourwork/womene mpowerment/overview.html).

However, the problem of women empowerment-like the "global concern about the environment"-has continued to give rise to more organizations (government and non-government), treaties, conventions, summits and conferences. The period opened with a resounding criticism of the whole empowerment concept and staunch defense of the status quo for women. In the bid to mainstream women and address their special needs, the UN declared the year 1975-1985 a decade for women. This decade which had equality, development and peace as its goals witnessed two prominent conferences-Mexico 1975, and Nairobi 1985-addressing women's issues and the way for- ward.

At the end of the decade, stock was taken regarding the attainment of its goals. While pockets of achievements were recorded, most countries including Nigeria experienced many obstacles towards the attainment of the goals of the decade. Among these obstacles are predominant traditional attitudes towards women; low priority attention by government to women's issues, the vulnerability of women to the worsening world economic situation, increasing maternal mortality, as well as conflicts in some societies. These constitute major obstacles towards the advancement of women.

The 1995 epoch-making Beijing conference was a follow-up on the Nairobi 1985 conference, and was aimed at assessing the extent of compliance of member countries in addressing women's issues in certain critical areas including health needs, discrimination, and access to credit, and so on. Following these conferences, more than 100 countries of the world launched new initiatives to improve the status of women (Lopez-Claros \& Zahidi, 2005).

Nigeria is one of those countries that ratified all the UN Conventions on women. In 1998, a national policy on women was designed by the Federal Government of Nigeria to protect women against all forms of discrimination. The policy merely exists on paper as little or nothing has been achieved since it came into being (Nwagbara \& Ering, 2007).

This policy was as a result of several years of resolutions by the United Nations, Organization of African Unity (OAU) as well as non-governmental organizations. Ubanna (2000) gave an insight on Article 18 (3) of the OAU Charter which Nigeria ratified in 1983. The charter, following the convention on Elimination of all forms of Discrimination against Women (CEDAW) and other conventions, made it obligatory for African countries to eliminate all forms of discrimination against women and ensure the protection of the rights of women and children (Nwagbara, Ering, Abia, \& Osuchukwu, 2007).

Since the Beijing conference in 1995, the Nigerian government has formulated policies on women in the areas of health, education, employment, agriculture, culture and industry. To ensure that these policies were effectively implemented, it was enshrined in Chapter 11 Section 17 (2) of the 1999 constitution of the Federal Republic of Nigeria where it was emphasized that "every citizen shall have equal rights, obligations and opportunities before the law".

In the area of education, the educational policy made it mandatory for women to receive proper education as enshrined in Chapter 11 Section 17 (2) of the same constitution. According to Ubanna (2000):

"The highlight of the policy was that the Nigerian woman should enjoy the full benefits of contemporary living. They required basic education to contribute meaningfully to the development of the country. The policy also forbids through legal sanctions, the withdrawal of girls under 18 from school for marriage."

There are also policies on health, culture and employment. The health policy is to ensure, that women are protected from health problems of high maternal mortality, unsafe abortion, HIV/AIDS and other infectious diseases.

The national health policy functions to enhance the implementation of primary health care delivery system to meet the health need of women and children.

The policy on culture overhauled the nation's legal system 
hence permitting women to stand as sureties and also be able to bail suspects from police custody. It was this policy that pegged age of marriage at 18 . This policy also recognized women as primary environment managers, extractors and users of environmental resources and sought to ensure women's participation in national ecosystem management and control of environmental degradation (Nwagbara, Ering, Abia, \& Osuchukwu, 2007).

On the other hand, the employment policy was to ensure equal opportunities and equal pay for men and women with same qualification. In all, these policies, meant for the opening up of new challenges to Nigerian women are yet to be properly implemented.

One policy which has engaged the attention of scholars in Nigeria is the year 2000 policy on women that was enacted by President Olusegun Obasanjo (Salihu, 2001; Para-Mallam, 2006; Afolabi, 2008; Adeleke, 2012). In a study to evaluate the impact of the 2000 policy on women farmers in Akungba and Oka Akoko areas of Ondo State, Adeleke's (2012) findings suggest that the policy has not impacted positively on the women. Of the five (5) key substantive issues in the studyaccess to land, labour and water, modern technology, credit and access to training in agricultural production and utilization-all the respondents complained of lack of access. Based on the findings, Adeleke (2012) concluded as follows:

"Despite the implementation strategies that were endorsed by former President Olusegun Obasanjo in 2000, women still have limited access to modern, improved techniques and there have been no much improvement in general working-conditions of this particular set of women under study."

Essentially, the above findings support earlier studies carried out by scholars such as Damisa and Yohanna (2007) and Afolabi (2008). On her part, Salihu (2001) lamented that there has been little qualitative change in the lives of women since Obasanjo's regime, arguing that:

"What positive development there has been is not a direct consequence of the leadership of the regime, but a systemic benefit as can only be engendered by a regime which comes after a military dictatorship such as Nigeria experienced. This is why the observable changes themselves are peripheral, because they have not challenged the existing structures of oppression."

Of all the studies on the national policy on women cited in this paper, the work of Para-Mallam (2006) is outstanding in its ability to present a graphic analysis of the policy and its loopholes. In a qualitative and quantitative analysis of the national policy on women and the challenges in mainstreaming gender issues in Nigeria, Para-Mallam (2006) summarized the problems within and around the year 2000 policy on women as follows:

“...awareness of the policy is low among most women. Consequently, there is no concerted agenda to push for its implementation. The gender management system put in place by the Federal Ministry of Women Affairs to oversee the mainstreaming of gender is undermined by institutionalised and routinised gender bias and distortions in the wider policy environment... successful implementation of policy objectives remains elusive in the absence of com- prehensive measures to reverse significant gender disparities in access to socioeconomic resources, opportunities and benefits."

Hence, while Nigeria ratified all the international conventions that gave rise to these policies, there is little political will for their full implementation. Some of them exist just on paper and the psyche of the formulators. Nigerian women are yet to reap the full benefits of the policies. A litany of factors, ranging from cultural and religious practices, to illiteracy and patriarchy function to compound the problem of Nigerian women's participation in decision-making to influence policies which affect them (Nwagbara, Ering, Abia, \& Osuchukwu, 2007).

An assessment of the extent to which women have attained equality in the critical areas of economic participation, economic opportunity, political empowerment, educational attainment, health and well-being undertaken of 58 countries shows that no country has managed to eliminate gender gap (Lopez-Claros \& Zahidi, 2005). The only African country included in that survey, Egypt, ranked 58th thus occupying the lowest rank. Yet Egypt and some other developing countries are performing better than Nigeria as evidenced in development studies of developing countries (World Bank, 2001; Economist, 2000).

The deplorable status of women is universal and not a recent phenomenon. Fu Hsuan, a 3rd century scholar had observed this of women in his era. Fu Hsuan in Bullough (1971) cited in Tischler, Whitten and Hunter (1986) observes:

\begin{abstract}
"Bitter indeed it is to be born a woman; it is difficult to image anything so low! Boys can stand openly at the front gate, they are treated like god as soon as they are born... but a girl is reared without joy or love, and no one in her family really cares for her; grown up she has to hide in the inner rooms; cover her head, be afraid to look others in the face, and no one sheds a tear when she is married off..."
\end{abstract}

In the contemporary time, women encounter worse prejudices and discrimination, albeit, subtly. These social vices against women have been condemned by Montagu (1982) who states:

"We need to catch up to the social changes which have occurred during the last fifty years, to adjust our ideas and practices to those changes which, on the whole have been liberating and beneficial. Because so many of us still live by beliefs which belong to an outmoded way of life, we tend to become confused and upset when confronted with the living realities of our time, and to commit the sort of follies that those who believe in stupidities will always commit."

Women in Nigeria contribute to national development through their multiple roles which were accorded little recognition. Women work longer hours and have less rest compared to their male counterparts. Rural women have restricted access to productive resources and have minimal access to credit facilities in relation to their male counterparts (Ezumah, 1988). In this era of modern technology and globalization, prevailing circumstances and trends such as conflicts, economic setback, illiteracy, unemployment, environmental degradation and diseases such as HIV/AIDS have contributed to deepening social inequality within the country context (Ogbuagu, 2004). 
As James and James (1995) noted, women who are the cornerstone and foundation of all societies are generally underrepresented and devalued. Montagu (1982) described the prevailing scenario of gender based inequality more succinctly:

“...If women have passed through the period of the abolition of discriminations against them, they have not yet successfully weathered the period of emancipation. For millennia women have been treated as the "inferior race" of the masculine world.”

Thus traditional beliefs based on gender differentiation has been a root cause of the yawning gap of social inequality between the male and female sexes and by implication a major obstacle to women empowerment in Nigeria. To redress this situation, one would expect that the principle of equity or social justice would be the watch word of agencies charged with empowering women in Nigeria through legislations and formulation of policies and programmes that are gender sensitive. The principle of social justice requires that everyone be provided with equal opportunities for self development and self actualization irrespective of sex, class, religion, ethnic background, HIV status or disability.

\section{Looking Forward: Some Critical Reflections}

One contribution to the empowerment debate that has served as a useful tool of reference is the model provided by Mullender and Ward (1991). These scholars' model of empowerment is based "explicitly on an anti-oppressive perspective and suggests three simple questions to be addressed by those concerned that participatory approaches achieve their empowerment potential" (Crawley, 1998). The questions are as follows:

1. What are the problems to be tackled?

2. Why do the problems exist? And,

3. How can we bring about change?

These questions are vital and those concerned with policies to redress the present imbalance in the status of women in $\mathrm{Ni}$ geria do not seem to be guided by them given the little achievement in this regard. Highlights of women's problems in Nigeria which have been fairly identified by government and non-government agencies are:

$>$ Subordinate status reinforced by gender roles and patriarchy,

$>$ High level of illiteracy,

$>$ Lack of access to resources-technology, credit, information, etc.,

$>$ Harmful traditional practices such as female genital mutilation/cutting, widowhood rites, and male-child preference,

$>$ Lack of access to decision-making through effective political participation,

$>$ Double burden/oppression through domestic activities,

$>$ Vulnerability to conflicts and diseases and infections such as malaria and HIV/AIDS.

Scholars have continued to lament about the little result attained by the various efforts at women empowerment in Nigeria and Africa in general (Mwangola, 2006; Madunagu, 2007). Their worry is best understood against the background of Mullender and Ward's (1991) second question as to why the problems exist in the first instance. Mill (1865) has since provided an explanation that "custom; grounded either in a prejudice, or in the present constitution of society, which, making almost every woman, socially speaking, an appendage of some man, enables men to take systematically the lion's share of what belongs to both". Re-echoing the view of Mill, Gardiner (1997) notes that the "legal subordination of women with marriage was the basis of women's subjection in the political and economic spheres".

Addressing the problems squarely will no doubt amount to liberating women from their relegation to the background and mainstreaming them into key decision-making spheres of the society. Lenin (1972) cited in Madunagu (2007) noted that the task of liberating women from their oppressed status is an arduous one which cannot be accomplished by mere exhortation. Commenting further on this, Lenin observed that the struggle to uplift the status of women through their liberation will "be $a$ long one, and it demands radical reconstruction both of the social technique and of morals".

The traditional perspective of women's subjugation to domestic activities, while men occupy super-ordinate status because they earn a living working outside the home, has been used by functionalist theorists to explain women's low status in the society and persistence of gender-role socialization. Thus, rather than serving to uplift the status of women in the contemporary times, the increasing globalization and advancement in technology and information have continued to widen the yawning gap of social inequality between men and women as the men control key economic and social resources while the women continue to be hemmed and chained at home by patriarchy. Commenting on this negative attitude of male-dominance against women, Montagu (1982) observes:

“... Contemporary men are, for the most part, still living in a Victorian world of their own. That world is out of harmony with that in which women live and most men haven't yet awakened to that fact... To live by the nineteenth-century standards in a twentieth-century world is an anachronism."

Men who instituted the oppression of women in society would want to perpetuate it as long as it functions in their favour. Thus, efforts at improving women's status to that of equality with men would have not yielded any meaningful result. Concerning this issue, Mill (1970) observes: "I believe that their disabilities elsewhere are only clung to in order to maintain their subordination in domestic life; because the generality of the male sex cannot yet tolerate the idea of living with an equal". In a similar vein, Barrett (1982) observes of the British society:

"Many popular remedies to improve women's economic
status paradoxically reinforce gender-based economic roles:
the welfare system reinforces the expectation of female
dependency; comparable worth pay admits gender dis-
tinctions; equal pay keeps women out of high-status jobs;
wages for housework, part-time, flexi-time, all reinforce
traditional stereotypes while facilitating flexibility for
women as homemakers, thereby reducing stress in tradi-
tional families and accommodating gender-role distinc-
tions."

Hence, the traditional and functionalist perspectives make it clear that while the problems of women are obvious, the forces of patriarchal society which perpetuate them, make it difficult, if not impossible, to empower women to the tune of elevating their social status to that of equality with men. 


\section{Conclusion and Recommendations}

The concern about gender issues and the disadvantaged status of women and their special needs is indeed a global one, giving rise to series of workshops, seminars, conferences and forums at the local, national, and international levels. The Nigerian government has indeed demonstrated superficial commitment to women empowerment through policies and programmes designed for women that have not yielded the desired impacts due to absence of concerted agenda to push for their implementation. As such, women's status remains deplorably low in Nigeria and their special economic, social and other needs are not met. The major constraints in realizing gender equality and women empowerment in Nigeria are: an unsupportive legal environment, inadequate resources and the mindset that is not open to new approaches in addressing the needs of women (Madunagu, 2007).

Past and current policies and programmes of government basically serve to consolidate existing patterns of gender inequality. For a proper empowerment strategy that will take into account the questions of what are the problems to be tackled? Why are the problems in existence? And how the problems could be solved, it is therefore recommended as follows:

1) Existing and potential policies and programmes of government should be designed to open up equality possibilities for men and women rather than widening the yawning gap of social inequality between both sexes.

2) Existing and potential policies should be reviewed to examine whether or not they serve as enforcement mechanisms of existing gender roles.

3) Policy-makers in Nigeria should abide by the principle of social justice and practice it by equally involving men and women in making policies that concern their welfare.

4) Policy makers should be more innovative such that new and existing policy options can blend especially where such approach will be beneficial to both men and women equitably.

5) Reform in the laws affecting the status of women generally is an essential first step in achieving gender equality. The fundamental human rights of women should be protected by the laws of the land.

6) Educational reforms should not only ensure that equity in school enrolment is monitored, loopholes that encourage girl-child drop out should be sealed and monitored effectively.

7) Discriminatory traditional practices against women should be stopped forthwith and future perpetrators should be made to face squarely the wrought of the law.

8) Adequate sensitization of men and women on the gains of women empowerment should be carried out by government and non-government agencies in every community.

\section{REFERENCES}

Adekanye, T. O. (1988). Women in African agriculture. Journal of the Institute of African Studies, 3, 1-4.

Adeleke, J. O. (2012). Effects of the national policy implementation strategy on the working conditions of women in agricultural developemnt: A case study of Akungba and Oka Akoko, Ondo State, Nigeria. British Journal of Arts \& Social Sciences, 5, 315-324.

Afolabi, M. M. (2008). Women as pillars of national economy in Nigeria: A study of economic activities of rural women in six local Government Areas of Ondo State. International Association for Feminist Economy, Torino, 19 June-21 July 2008.

Ake, C. (1994). Democratization of disempowerment in Africa. Ikeja:
Malthouse Press.

Barrett, N. (1982). Obstacles to economic parity for women. American Economic Review, 72, 164-165.

Boserup, E. (1980). Women's role in economic development. New York: St. Martins Press.

Crawley, H. (1998). Living up to the empowerment claims: The potential of PRA. In I. Guijt, \& M. K. Shah (Eds.), The myth of community. London: Intermediate Technology Publications.

Damisa, M. A., \& Yohanna, M. (2007). Role of rural women in farm management decision making process: Ordered probit analysis. Trends in Applied Science Research, 2, 241-245. doi:10.3923/tasr.2007.241.245

Economist (2000). A survey of Nigeria: Here is hoping. Economist, 1,1. Ezumah, N. N. (1988). Women in agriculture: Neglect of women’s role, Journal of the Institute of African Studies, 3, 9-15.

Famoriyo, S. (1988). The significance of women in Nigeria agriculture. Journal of the Institute of African Studies, 3, 1-4.

Gabriel, A. O. (2000). Women empowerment in the Niger-Delta: Past, present and future. Journal of Niger Delta Research, 2, 21-39.

Gajanayake, S. J. (1993). Community empowerment: A participatory training manual on community project development. Il: Office of International Training and Consultation.

Garba, P. K. (1997). A strategy for empowering women: Application to trade union activities. In P. K. Garba, et al. (Eds.), Women and economic reforms in Nigeria. Ibadan: Women's Research and Documentation Centre.

Gardiner, J. (1997). Gender, care and economics. London: MacMillan Press.

Griffin, V. (1989). Women, development and empowerment: A pacific feminist perspective. Kuala Lumpur: Asian and Pacific Development Centre.

James, V. U., \& James, M. M. (1995). The current and future directions for African women farmers. In V. U. James (Ed.), Women and sustainable development in Africa. CT: Praeger Publishers.

Lopez-Claros, A., \& Zahidi, S. (2005).Women's empowerment: Measuring the global gender gap. URL (last checked 8 April 2006). http://ncwo-online.org/data/images/WorldEconomicForum.pdf

Madunagu, B. (2007). Women's health and empowerment: Speeches, essays and lectures (1995-2006). Calabar: Clear Lines Publications.

Mill, J. S. (1865). Principles of political economy. London: Longman.

Mill, J. S. (1970). The subjection of women. In A. S. Rossi (Ed.), Essays on sex equality. Chicago: Chicago University Press.

Montagu, A. (1982). Introduction. In J. E. Fairchild (Ed.), Women, society and sex. New York: McMlii.

Mullender, A., \& Ward, D. (1991). Self-directed groupwork: Users take action for empowerment. London: Whiting and Birch.

Mwangola, M. S. (2006). Looking, back, moving forward: Relections on Forum'85. CODESRIA Bulletin, 1-2, 6-7.

Nwagbara, E. N., Ering, S. O., Abia, R. P., \& Osuchukwu, N. C. (2007). Strategies for involving women in framing environmental policies: A critical appraisal of the Nigeria situation. Calabar Journal of Politics and Administration, 4, 118-132.

Nwagbara, E. N., \& Ering, S. O. (2007). A sociological analysis of political gender-balancing in Nigeria. Journal of Research in $\mathrm{Na}$ tional Development, 5, 51-62.

Ogbuagu, S. (2004). Gender, population and environmental issues. Owerri: Ark Publishers.

Ogunlela, Y. I., \& Mukhtar, A. A. (2009). Gender issues in agriculture and rural development in Nigeria: The role of women. Humanities and Social Sciences Journal, 4, 19-30.

Omonijo, B., Rotimi, A., \& Agande, B. (2007). Census: Kano beats Lagos. Vanguard Newspaper, 23, Article ID: 60243.

Para-Mallam, O. J. (2006). The national policy on women and the challenges of mainstreaming gender issues in Nigeria, 1985-2005. Ph.D. Thesis, Leeds: University of Leeds.

Rowlands, J. (1992). What is empowerment? The challenge of researching women, empowerment and development in Honduras. GAPP Conference on Participatory Development, London, 9-10 July 1992.

Salihu, A. (2001). Nigerian women and the Obasanjo regime. DPMN Bulletin. URL (last checked 25 July 2012). 


\section{E. N. NWAGBARA ET AL.}

http://www.dpmf.org/images/nigeria-women-amina-sept-2001.html Tischler, H. L., Whitten, P., \& Hunter, D. E. K. (1986). Introduction to Sociology (2nd ed.). New York: Holt, Rinehart and Winston.

Ubanna, S. (2000). Unchaining women. Newswatch Magazine, 32, 1314.

UNDP (2012). URL (last checked 7 July 2012).

http://www.undp.org/content/undp/en/home/ourwork/womenempow erment/overview.html

UNFPA (2012). URL (last checked 7 July 2012).

http://www.unfpa.org/gender/empowerment.htm

World Bank (2001). Tracking poverty: World development report 2000-2001. Oxford: Oxford University Press. 